Astraea, Vol. $2, \mathrm{No} 1, \mathbf{2 0} 1$
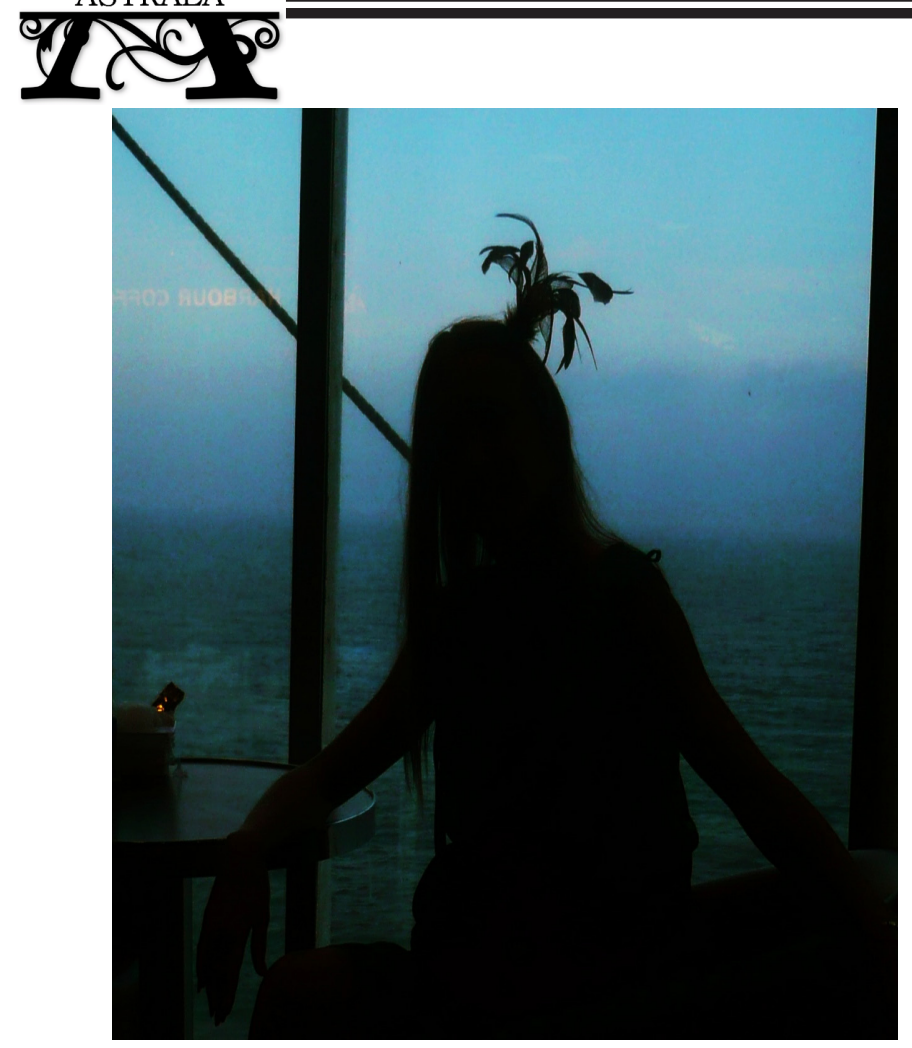

ХУДОЖНЯ ЛІТЕРАТУРА

\author{
АРЕЙ Леля Третій зайвий \\ ЗАДЛЯ ТРІУМФУ \\ ЕЛІЗАБЕТ РУДИНЕСКО \\ doi: 10.34142/astraea.2021.2.1.07
}

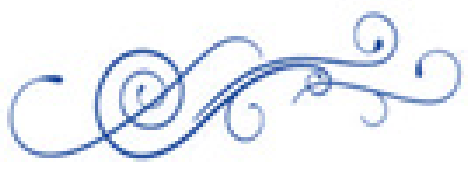

АРЕЙ Леля

E-mail:serka7@ukr.net

Напевно, вже реляцією традиційних елементів сюжету - назви та розв’язки - оповідання «Третій зайвий» претендує на читача особливого, якщо не здатного до ризику, то щонайменше допитливого, готового прожити невеликий простір тексту хоча б з метою очікування новизни історії під провокативно формульними словами картуша-назви. I такий читач дістане нагороду, відчутну навіть для спокушеного законом дубль-фіналу звичного для сучасної літератури. Незважаючи на те, що декодування назви в останніх рядках тексту відбувається в стилі відступництва «від доби прямого погляду до доби уникнення». Це визначення реальності відомого філософа й психоаналітика Елізабет Рудинеско можна було б застосувати для характеристики в оповіданні долі людини комфорту, яка підпорядковує життя культу розумної (простої) необхідності, де немає місця пристрастям чи афектам, де все покликане бути альтернативою фройдівській метафорі людини - не господаря у власному домі, уже тому, що фінансовий достаток дозволяє цій людині «нефройдівській» примножувати кількість будівель, власником яких вона є. Але саме в світлі теорії Рудинеско людина комфорту з оповідання «Третій зайвий» постає суб’єктом, який зазнав невимовної тотальної поразки. Людина комфорту з оповідання може не спостерегти взаємозалежності безпроблемності свого проживання в соціумі та своєї (C) Arey Lelya, Khomenko Halyna, 2021 
репродуктивної смерті, викликаної в’ялістю, виснаженням клітин, які мають призначення продовжити життя в дітях. Вона може не зауважити, що відкриття наукою таємниці початку життя і баналізована вже практика ЕКЗ супровод жуються періодичним бунтом ірраціонального, несвідомого і надсвідомого, так що передбачене розумним планом перекреслиться випадковою зустріччю статевих клітин. Але в очах читача катастрофа простого спокою постане більш жахливою, аніж катастрофа вибухових подій. I читач переживе необхідність виходу із зони комфорту персонажів, які відмовляються від не планованої, до того ж фізично слабкої третьої дитини, як виходили в пустелю за захисні мури мешканці давньогрецького міста Каміроса, щоб серед небезпек і ризику відчути справжнє життя, щоб пережити в пустелі непередбачуваного власну складність як виклик простоті звичайно зрозумілого.

Галина Хоменко кандидатка філологічних наук, доцентка, доцентка кафедри украӥнської літератури та журналістики імені Леоніда Ушкалова, Харківський національний педагогічний університет імені Г.С. Сковороди (Украӥна)

\section{Третій зайвий}

Присвячуеться О. М. і Г.З.

Рита дивилася на себе у дзеркало. Доглянута, шикарна жінка без віку - їй можна було дати за двадцять та близько п'ятидесяти - сумно посміхалась Риті зі сріблястої поверхні. Сяюча шкіра обличчя, бликсучі здорові пасми волосся, підлітково-ідеальна фігура німфетки, ділова сукня, скромна норкова куртка випромінювали успіх, добробут і вдачу. Очі безнадійно дивились у дзеркало, зустрічаючись із відсутністю зморшок. Рита намагалася зрозуміти, з'ясувати для себе: чому?

Коли вона ходила в дитсадок та школу, іï подружки грали в дочки-матері та мріяли про родину і дітей. Вона ніколи не мріяла про це, оскільки думала, що інакше просто бути не може. Звичайно, у неї будуть діти, обов’язково в неї буде 
родина, а як же ще. Навіщо мріяти про те, що обов’язково станеться? Вона не поспішала. Поруч із нею були успішні чоловіки, які фокусувалися, перш за все, навколо власної кар'єри. Сучасний чоловік соціальні сходи сприймає як первісний полювання або риболовлю - ставиться дуже серйозно. Кар'єра для нього дорівнюється забиванню мамонта. Саме такого - розумного, практичного та успішного вона обрала. Рита теж була амбіційна, їй хотілося чогось досягти, щоб нею пишалися... Із дітьми вони не квапились, вважали, що встигнуть. Так багато усього цікавого навколо! Діти все одно будуть, тільки з часом...

Отже, Рита та Едик були інтелегентними (спокійно-правильними), успішними та благополучними людьми. Можна сказати, вони були заможні. В обох була вражаюча кар'єра, однак працювали вони не через гроші, а заради самореалізації, тому гроші до них просто липли без усіляких зусиль із їхнього боку, причому не в першому поколінні. Їхні батьки були також дуже заможні.

Спочатку вони вчилися в «інститутах», насолоджуючись спілкуванням одне з одним, відвідуючи з друзями клуби, концерти та казино, маючи можливість подорожувати... Монако, Іспанія, Індія, Куба, Італія, Франція... Необмеженість у грошах давала можливість проводити час як хочеться, однак це не значило - проводити його щасливо. Роздратування могли викликати різні дрібниці. Не можна сказати, що їхні стосунки були палко-пристрасними. Готелі були розкішні, а стосунки - спокійні, як у інтеліґентних освічених людей, які вміють пристойно себе поводити. Дах не зносило... Але було спокійно і затишно, дружньо-комфортно.

Потім, паралельно з перспективним підприємництвом, за планом ішла аспірантура, причому кандидатські ступені їм потрібні були не для роботи, оскільки вони займалися бізнесом, а тому, що це - престижно. Таким чином, захисти їхніх кандидатських дисертацій пройшли дуже легко, гладесенько-рівнесенько. без сучка - без задоринки. От якщо б вони дійсно були вченими і робили якісь серйозні відкриття в науці, тоді, звичайно ж, захистити дисертацію було б неймовірно складно. Однак оскільки вони були бізнесменами і бізнеследями, то неприємності у них були тільки в бізнесі: періодичні, які вирішуються з часом.

Вони продовжували багато мандрувати, однак ніколи не могли цікаво розповісти про країни, які відвідали, поділитися враженнями. Із них кліщами потрібно було тягнути інформацію, причому скудні (убогі) свідчення, як правило, стосувалися рівеню і сервісу фешенебельних готелів, в яких вони мешкали, шикарних ресторанів, в яких вони їли, транспорту, досягнень науково-техніч- 
ного прогресу, техніки, і ніколи питань історії, культури країни, звичаїв. До музеїв вони зрідка ходили, частіше з неохотою, завжди зі слухавкою-гідом, оскільки поїздки були індивидуальні, а не групові, але при цьому на екскурсовода їм навіть не приходило в голову розкошелитися.

Вони «зустрічалися» сім років - поки вчилися і захищалися, потім разом жили п'ять років, щоб перевірити, чи можуть уживатися під одним дахом, і через дванадцять років спілкування вирішили одружитися - зареєструвати свій шлюб. Особливої палкості між ними не простежувалося. Все було зручно, комфортно, цивілізовано, майже правильно, виходячи зі стосунків мужчини і жінки західного типу культури. У них було дві розкішних квартири в центрі міста: одна в архітектурному пам'ятнику - 260 м - у ній вони жили, інша в новопобудованому будинку - 170 м - яку вони здавали, і ще три однокімнатних квартири тільки для здавання, також у центрі. На гроші від здавання квартир можна було безбідно жити і мандрувати, не працюючи при цьому. Однак Рита і Едик були активними, працювали заради процесу, який давав прибуток значно більший, ніж здача нерухомості. Вони купили величезну ділянку землі і будували дім. Життя було спокійне й розмірене.

Їм було за тридцять років. І за віком, і за фінансовими можливостями, і за сімейним станом вони обоє водночас прийшли до думки про те, що можна було б «завести» дитину. Кому ж іще, якщо не їм?! Таким чином, вони перестали оберігатися. I навіть у їхніх сексуальних стосунках з'явилася якась окриленість, яка раніше не простежувалася. Однак, через певний термін у Рити, так само, як і завжди, почалися місячні. Вона злегка засумувала, оскільки раніше у неї завжди виходило те, що вона запланувала. А цього разу ситуація вийшла 3-під контролю. Однак вона вирішила не переживати. У «Космополітені» прочитала, що пари, яким вдається завагітніти упродовж половини року, вважаються здоровими. Вони продовжували далі, і кожного разу під час місячних Рита «сумувала», а після чотирьох місяців навіть всплакнула.

Едик ії заспокоював, адже півроку ще не пройшло, хвилюватися немає про що. Але сум Рити став переходити в початкову нудьгу. Вона не знала, що їй робити. Вона не хотіла думати про те, що може статись, що у неї ніколи не буде дітей. Вона не хотіла про це думати, однак саме ця думка кружляла в її голові. Поступово вона стала уявляти, що буде робити, якщо у неї дітей не буде. Рита мала успішне життя, майже всі їй заздрили, тому що здавалося, що неможливо- 


\section{}

го дня неї не існує: і в психологічному (у неї був сильний характер і стратегічне мислення) і в матеріальному сенсі. Вона буде працювати, будувати, мандрувати, спілкуватись, відпочивати. Хіба цього не досить? До цього хочуть прийти всі. Тільки пари, у яких діти є, можуть це собі дозволити після п'ятидесяти років, коли діти виростуть. А вони з Едиком можуть бути щасливими уже в тридцять! Тільки потрібно прийняти, що дітей не буде, і змиритися з цим.

Як тільки вона починала це усвідомлювати, з середини, із сонячного сплетіння, починало щось тягнути, їй ставало себе шкода, на очі наверталися сльози... Чи витримає це Едик?! Чи буде з нею, якщо вона не народить дитину?! Чи буде вона з ним?! Рита вирішила йти далі... Намагатися завагітніти...

Пройшло півроку, а Рита так і не завагітніла. Тоді вони вирішили звернутися до лікаря. Природно, вони вибрали приватну, дуже дорогу клініку. Гарний інтер'єр мусив себе виправдовувати. Паціенти клініки були людьми аж ніяк не бідними, яким пропонувався широкий діапазон процедур. Вони почали сдавати числені аналізи, які коштували неймовірних грошей, а також вимагали часу. Замість роботи тепер Рита та Едик ходили в приватну клініку. Однак окрім необхідних аналізів, щоб було не дуже тоскно, ім пропонували додаткові процедури: масаж, вітаміни, омолодження, косметологія, і навіть парикмахерські та манікюрні послуги. Спочатку це було схоже на відпустку, але тижднів через три стало якось втомлювати, через півтора месяці викликати не дуже гарні підозри, а через три месяці, коли була витрачена солідна сума, а діагноз так і не встановлено, Едик боязко вимовив:

- По-моєму, із нас викачують гроші, а допомогати нам ніхто не збирається, оскільки їм це ЕКЗномічно не вигідно. Як бізнесмен я їх частково розумію: безглуздо відпускати курку, що несе золоті яйця.

Едик вимовив вголос те, про що весь час думала Рита, однак не наважувалася зізнатися в цьому навіть самій собі. Вона вже була на межі нервового зриву. Заспокійливі масажі не заспокоювали, а лише дратували. I коли Едик озвучив вголос те, про що вона здогадувалася вже два місяці, однак боялася собі в цьому зізнатися, у неї просто почалась істерика - прямо в приватній клініці. Рита схлипувала, переривчасті схлипування переходили у крик. Лікар відреагував негайно. Він, намагаючись здаватися професійно спокійним, гучніше, ніж зазвичай, віддав медсестрі розпорядження:

- Покладіть пацієнтку в ліжко! Для початку зробіть внутрішньом'язово 5 мг фенозепаму! 
- П’ять?! - перепитала медсестра, та якось напружилась.

Лікар на неї дивився.

- П’ять, а потім через чотири години я подивлюся, і вколемо ще п’ять...

Медсестра занервувала, лікар це помітив. Помітили й Рита, продовжуючи схлипувати, з Едиком. Вони не розуміли, про що говорять фахівці, однак було не комфортно.

- Добре, - сказав лікар, - зараз введомо 8 мг, а потім я вирішу!

Едик інтуїтивно швидко зрозумів, у чому справа, схопив Риту на руки, шепочучи їй на вушко:

- Тікаймо звідси!

Вона перестала плакати. У коридорі він опустив їі на підлогу та, тримаючи за руку, біг до виходу. Вона бігла разом із ним:

- Що сталося!? - спитала вона на бігу...

- Не знаю, - відповів, не зупиняючись, Едик, - потім поясню.

У коридор за ними вибігла медсестра і стала кричати:

- Рито Миколаївно! Вам не можна бігати! Зупиніться!

Назустріч їм вийшла інша жінка в білому, з посмішкою, спробувала їм щось сказати, щоб зупинити, але вони їі відштовхнули і побігли далі. Прямо в лікарняних піжамах вони вискочили на вулицю, щоб якнайшвидше сісти до машини й від”іхати. Медсестра вискочила на крильце:

- Ви свої речі не забрали! - кричала вона їм навздогін.

Однак вони вже їхали по дорозі. За речами, які залишились у гардеробній приватної клініки, потім заїхала подруга Рити, і за нотаріально завіреною довіреністю забрала те, за чим Рита й Едик зайти вже не наважувалися, а залишати було шкода - вже ж надто дорогі речі.

Вони вирішили, що в нашій країні дуже погана медицина, непорядні лікарі, потрібно їхати до Німеччини й робити все там. На роботі Рита пояснила і керівництву, і колегам, що вони планують завагітніти, що вони здорові, ніяких перешкод не встановили, принаймні, їх не озвучили. Однак, наша медицина не на достатньому рівні, тому їй доведеться певний час проводити за кордоном. Однак вона буде працювати, займатися документами, електорнною поштою їй можна буде все надсилати, вона все буде робити.

Більше двох років пішло на спроби завагітніти у Німеччині. Рита сумувала. Намагалася переключитися. Навіть із часом почала намагатися змиритися 3 думкою, що дітей у них може і не буде... Вона вирішила зайнятися новою спра- 
вою, організувати міжнародний бізнес з Італією. Почала вчити італійську та їдити у Мілан.

Однак думка про дитину не відпускала їі...

Після приватної клініки та Німеччини за рЕКЗмендацією перевірених надійних знайомих вони звернулися до спеціаліста української бюджетної лікарні - «Центр планування родини». ГінЕКЗлог Галина Анатолї̈вна, оглянула Риту на кріслі, порЕКЗмендувала діагностувати непроходимість маткових труб, для чого призначила рентген маткових труб. У «Центрі» це коштувало 1000 гривень. Рентген підтвердив діагноз лікаря. У Рити була непрохідність маткових труб, що не встановили ані в приватній лікарні, ані німецькі фахівці. Галина Анатоліївна запропонувала зробити операцію - лапароскопію маткових труб. Операція коштувала 6000 гривень. Перед операцією Едику зробили спермограму, яка, не випадково, виявилася поганою. Зрозуміло, Галина Анатоліївна, щоб не бездіяти, призначила додаткову терапевтичну підтримку - величезний пакунок вітамінів і пігулочок для різних систем людського організму: і Едику і Риті, які вони в’яло, однак, самозабутньо, в таємниці від самих себе сподіваючись на успіх, слухняно і регулярно пили. Однак, лапароскопія не допомогла. I так млявеньким сперматозоїдам було просто не під силу подолати числені бугорочки маткових труб, навіть під дією дорогих вітамінів і ліків.

Рита плакала ночами, таємно підглядала за жінками з дітьми на вулиці та на дитячих майданчиках, сумувала, поступово втрачаючи останні крихти надії. Едик дуже хвилювався за Риту. Він майже змирився з тим, що дітей у них не буде, однак Риту йому було шкода, але заспокоїти їі він не міг, не знав як. Галина Анатоліївна запропонувала останній варіант - ЕКЗ. Однак перед тим, як робити ЕКЗ, звичайно ж - вітамінчики. За ці роки Риті та Едику було вже нестерпно не те, що пити вітаміни, але навіть дивитися на них. Однак, стримуючи блювотні позиви, вони мужньо продовжували їх пити, вірішивши зробити все можливе, щоб потім не дорікати собі, що від чогось відмовились та не використали зовсім мізерний шанс, готуючись до ЕКЗ.

Їм, байдужим до грошей, повідомили, що ЕКЗ - екстракорпоральне запліднення - коштувало від сорока до п’ятидесяти тисяч гривень (п’ять-шість тисяч доларів). Попередили, що процедуру можна повторювати декілька разів: три, загальна сума сто двадцять - сто п’ятьдесят тисяч гривень (п’ятнадцять вісімнадцять тисяч доларів). Може, від тривалості та попередніх невдач щось 
зламалося в Риті. Окрім нудьги додалася психологічна втома та бажання припинити, залишити все, як є.

Цього разу, незважаючи на таку ж, як і раніше матеріальну стабільність - вони могли дозволити собі майже все - коли Едик і Рита почули суму, вони красномовно вдвох водночас замовкли. Емоційна втома вплинула на небажання діяти, відмовитись від ідеї мати дитину взагалі, оскільки було дуже страшно знов відчути розчарування від невдачі. Галина Анатолї̈на уважно на них дивилася, і хвилини через дві після паузи сказала, що на неї чекають наступні пацієнти. Едик зрозумів, що потрібно щось сказати і вимовив:

- Нам потрібно порадитись і подумати...

- Добре, - сказала Галина Анатоліївна - коли подумаєте, подзвоніть...

Вони вийшли на вулицю. Падав приємний м’який сніг. Рита здавалась стурбованою, а Едику потрібно було їхати на ділову зустріч. Він поспішав. Вона попросила його трохи пройтись вулицею, адже вони весь час працюють, і майже ніколи не гуляють. Він ввічливо погодився, хоча знав, що запізнюється. Вони йшли вулицею. На іншому боці дороги йшла шикарна молода жінка з дівчинкою за руку. Дівчинка була дуже красива. У руці жінка тримала футляр від скрипки. Прямо перед ними стояла інша - репетуюча на дитину, що плакала, - жінка. Дитина хлипала, неначе задихаючись, і щось просила, а жінка не хотіла їй це давати. Рита заворожено дивилася на обох жінок. Одна, зі скрипкою, викликала у неї захоплення і навіть заздрість, а інша - засудждення. «Чому все так несправедливо!?» - огорталося в голові у Рити. «Вона не гідна мати дитину! Вона на неї репетує! А у мене їі немає! Чому!?». Риті було боляче і сумно, і не хотілося вже взагалі нічого, тільки про все забути та заспокоїтись і щоб усе нарешті скінчилося.

Вони йшли далі, наближаючись до яскравої вітрини магазину. На одному з манекенів була модна норкова шубка, облямована соболем. Рита зупинилася, ïi очі несподівано запалали й загорілися. Едик це помітив. I вона відчула якесь бажання, що їі дуже здивувало, оскільки вона думала цієї миті, що вже ніколи нічого не захоче.

- Цікаво, скільки вона коштує? - почав вголос розмірковувати Едик. - Давай зайдемо, дізнаємось... - запропонував він.

Дивуючись собі, Рита заворожено увійшла до магазину й попросила шубу з вітрини, вважаючи, що робить це марно. Вона несподівано закохано дивилася на себе в дзеркало. Шуба коштувала сорок тисяч гривень, віддавали за трид- 


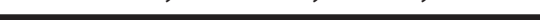

цять дві (чотири тисячі долларів). Едик цинічно подумав, що це дешевше, ніж ЕК3, і можна відразу купити. Ось вона. I Рита знов начебто посміхається...

- Ми подумаємо, - розсудливо сказав Едик, і вони вийшли з магазину.

Рита дивилась на вітрину. Дитина на вулиці продовжувала істерично плакати, а жінка, замість того, щоб якось ӥі заспокоїти, робила вигляд, що збирається йти, від чого малеча ще більше завивала. Шикарна жінка вже без футляра від скрипки повільно прогулювалася через дорогу. Вони спостерігали та переглядалися...

- А ти дійсно хочеш дитину? - спитав Едик у Рити. - Дивись, як вона репетує... А ця дамочка мінімум годину тут буде мерзнути, поки иї чадо на скрипочці грає. Хочеш шубу?!

- Цю?

- Але тобі ж ця сподобалась...

- Хочу...

Едик пішов до крамниці й вийшов звідти через десять хвилин із пакетом у руці.

- Ну що, поїхали? А то мені на зустріч ще потрібно встигнути...

Вони швидко пішли до машини. Дорогою Рита милувалася краєвидами 3 вікна, і здалося, що вона потроху відтаює.

Увечері Рита довго милувалася собою у дзеркалі в новій шубі. А вночі вона раптом прокинулась і стала істерично кричати на Едика:

- Я хочу дитину! Мені не потрібні твої лахи! Я хочу дітей!

Зранку Едик зателефонував до Галини Анатоліївни й домовився про дату ЕК3. I тут все трапилось, як у казці...

Після першої спроби штучного запліднення Рита дуже сподівалася, що вони з Едиком увійдуть у той рідкісний відсоток щасливчиків, у яких все вийшло з першого разу. Вже через декілька днів вона стала уважно розгядати себе в дзеркалі та шукати ознаки вагітності в своїй фігурі, що змінилася. Їй здавалося, що животик вже з'явився, а речі вже складніше застібаються на талії та стегнах. Вона стала більше їсти, щоб дитинці нічого не бракувало, усе найсмачненьке, все для неї, для малечі...

УЗД було призначено через три тиждні після ЕКЗ. Рита була впевнена в тому, що вона вагітна, і відчувала себе дуже щасливою. На УЗД вона потягнула з собою Едика, який для цього переніс дуже важливу ділову зустріч. У «Цен- 
трі...» Едик сидів у коридорі, поки Риту оглядали. Через десять хвилин вона вийшла в сльозах із кабинету лікаря, не звертаючи уваги на Едика, пройшла повз нього, i, збігаючи вниз сходами, вискочила роздягнена на вулицю. Галина Анатоліївна підійшла до Едика і сказала, щоб він увійшов у кабінет. Замість того, щоб увійти, Едик кинувся за Ритою.

Без одягу вона добігла вже до кінця кварталу. Він кинувся иї наздоганяти i зробив це блискавично швидко. Едик зняв із себе куртку і накинув їі на плечі Риті:

- Що ти коїш?!... Ти ж застудишся!

- Я хочу застудитися, померти! У мене нічого не виходить!

- Звідки в тебе це, Рито?... Ти ж завжди така спокійна і розсудлива! Що ти робиш?!... Давай повернемось! На нас Галина Анатоліївна чекає!

Рита слухняно повернула в бік «Центру»...

- Я попереджала, - говорила м’яко і спокійно Галина Анатоліївна, - що 3 першого разу може не вийти. Зробимо другу спробу, але не зараз, а місяці через чотири... через п’ять. А поки що Вам потрібно повернутися до звичайного життя. Ходіть на роботу, переключіться, заспокойтесь. Я випишу підтримуючі препарати, які Ви будете пити вдвох. Будемо сподіватися, другого разу все вийде.

«Вітаміни» продовжувались...

Однак через п’ять місяців на другий раз теж нічого не вийшло. Інформацію про те, що не вагітна, на другий раз Рита сприйняла спокійно. Між Ритою та Едиком почало прослизати відчуження, яке Рита пристрасно підживлювала, усіляко провокуючи чоловіка на скандали. Едик почав подовгу затримуватися на роботі, щоб якомога пізніше з'являтися вдома і якомога менше бачити нещасну дружину. Рита почала його ревнувати, поки безпідставно, однак своїми ревнощами вона зародила в ньому сумніви, і він мимоволі почав дивитися на інших жінок - квітучих і красивих.

Через чотири місяці була призначена остання, третя процедура ЕКЗ. Рита вже нічого не чекала. Абсолютно пригнічена, вона сама через три тиждні пішла на УЗД. Галина Анатолї̈вна дуже довго оглядала їі, потім покликала свою колегу, і вони разом дивилися на монітор компьютера, вимовляючи якісь незрозумілі терміни.

Галина Анатолї̈вна взяла Риту за руку і дуже ніжно, з посмішкою, сказала:

- Вітаю, Ви - вагіті. 
- Як вагітна? - не розуміючи, не вірячи, шепотіла Рита, і сльози неслухняно котилися по її обличчю.

- Так...

- Це точно? - не вірила Рита...

- Точно. І навіть скажу більше - у Вас запліднилися дві яйцеклітини.

- Що це значить?

- Це значить, що у Вас буде дві дитинки.

- Як дві? А як же я зможу народити двох дітей? - підозріло вимовила Рита.

- Не хвилюйтеся. Зможете.

Рита тут же поїхала на роботу до Едика повідомити, що вона вагітна, і що у них буде не одина, а цілих дві дитинки. Едик, здається, був радий почути те, на що вже перестав надіятись, але сказав, що особисто про все поговорить із лікарем.

У кабінеті Галини Анатолї̈вни Едик відчував себе вже значно впевніше, однак якось недостатньо чисто. Думки були не світлі, і не райдужні, незважаючи на щасливі новини.

- Дякую, Галино Анатоліївно, - інтелігентно-доброзичливо говорив Едик. - Ми вже перестали надіятись...

Галина Анатоліївна м’яко дивилася на нього, втомлено передчуваючи тупі безглузді питання.

- Скажіть, - продовжував Едик, - Ви сказали, що дитинки буде дві... Розумієте, - починаючи м'ятися говорив він - ми якось не очікували, не розраховували... Це ж дуже велика відповідальність. Чи зуміємо ми підняти двоїх дітей... Може, можна щось зробити.

Галина Анатоліївна, працюючи в «Центрі...», думала, що ї̈ вже нічим не здивуєш, але навіть вона якось напружилася. Тон ӥі голосу став професійно відстороненим і холодним. Як лікарка у білому халаті вона говорила 3 «хворим», подсвідомо відчуваючи: «Гріх сміятися над убогими...».

- Можна, - з долею жорстокості говорила лікарка. - Можна зробити редукцію ембріона...

- Вибачте, я не зовсім зрозумів... Це як?

- Можна забрати зайву клітину... Правда, вона жива...

Очі Едика блиснули з надією:

- Це безпечно?

- Це дуже небезпечно. Ми можемо ушкодити клітину, що залишиться, й 
у Вашому випадку це буде значити залишитись без дітей, - жорстко і твердо винесла вердикт лікарка.

- Тоді нічого не треба, - налякано відмовився Едик, - вибачте, що забрав Ваш час...

Вагітність Рити протікала чудово й легко, на здивування. Мабуть, це була своєрідна компенсація за страждання, які вони пережили останнім часом.

Пологи пройшли так же легко, якщо можна повірити в те, що пологи, будь-які, бувають легкими. У пологовому будинку стомлена, але життєрадісна акушерка повідомила Едику:

- Татусику, вітаю із трійнею! Ти, прямо, статевий гигант!

У Едика було здивоване обличчя...

- Яка трійня?

- Така! Трійня! Троє хлопчиків! Третінький, правда, слабенький... Він же останесенький... Дісталося йому, мабуть... Хоча, радше, не дісталося... - розмірковувала акушерка. - Ну та нічого! Ви ж багаті! Піднімете! Зараз такі препарати! Були б гроші!...

Із пологового будинку «щасливі» Рита й Едик від’іжджали з двома гарними й здоровими хлопчиками. Рита хотіла відчувати радість, однак була дуже стомлена, спати вже не можна було так, як раніше. Це були незнайомі емоції: втома, до якої домішуються докори сумління, які намагаєшся придушити, однак це погано вдається. Чудову, вишукану й красиву пару чекало нове - складне, однак дуже цікаве, наповнене абсолютно іншим сенсом життя.

Медсестри із відділення немовлят, зовсім не байдужі до краси, захоплено дивилися на красиву пару:

- Ну що, ходімо дітей годувати? - сказала білявка руденькій.

- Скільки пляшечок робити? - спитала руденька. - Вісім?

- Дев'ять!

- Чому це дев’ять?!

- Так вони ж від третьої дитини вирішили відмовитись.

- Як це?! - із розширеними круглими очима запитала руденька.

- По-перше, вони його не планували, - відповіла білявка. - А по-друге, у нього слабкі фізичні показники...

Медсестри з сумом дивилися у вікно на розкішний білий Porsche, перев’язаний блакитним бантом, який Едик подарував Риті з нагоди народження їхніх дітей. 


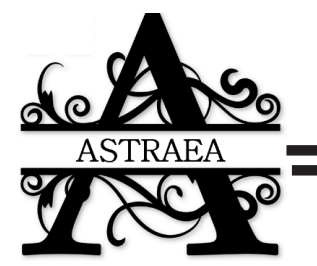

Astraea, Vol. 2, № 1, 2021

- Мабуть, Господь Бог не випадково не дає деяким людям дітей... сказала руденька. - Чи маємо ми право втручатися в Божий промисел... - Добре, ходімо дітей годувати... - сказала білявка.

Серпень 2013 - Жовтень 2016 Березень 2018

Отримано: 15.01 .2021

Рекомендовано: 25.03.2021

\section{Cite materials as:}

Arey, L., Khomenko, H. (2021). For Elizabeth Rudinesco's Triumph. Third wheel. Astraea, 2(1), doi: 10.34142/astraea.2021.2.1.07

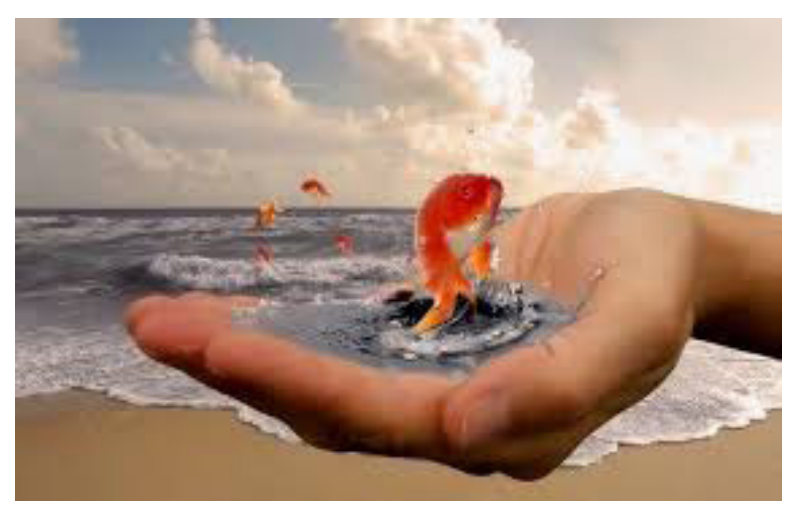

